\section{Post examination psychosis?}

Sir: Having relatively recently taken my MRCPsych 2 there is a large collection of unused papers, books and irrelevant literature lying in my bedroom.

During this summer while lying awake at night I began to hear very strange noises originating from the box of notes. Night by night the noise got louder. While my wife slept on I began to question my sanity.

Having been left an emotional wreck following the exams I began to wonder, is this a 'perception lacking external stimuli', was it hypnogogic or hypnopompic? Would I go on to develop delusions that my examiners were exacting revenge and a plot develop (more sinister than normal MRCPsych persecution syndrome); if so which ward would I end up on, would I end on a section? On a sweltering night at 3 o'clock in the morning it is amazing how the mind works.

Finally my wife found me crawling around the floor searching my notes. Just as she was thinking of calling the GP and getting me incarcerated I discovered a host of death watch beetles, presumably eating their way through my notes, and no doubt discussing the content of, for example, the number and relevance of serotonin receptors in the current theories of schizophrenia.

All notes were placed in a black bag and rapidly deposited in the garden shed. I would suggest to all those with boxes of unused notes in their bedrooms that they hastily do likewise.

alastair Neale, Young People's Centre, Mount Gould Hospital, Plymouth PLA 7QD

\title{
Erratum
}

'Mental Health Review Tribunals in practice' by G. E. Langley (Psychiatric Bulletin, 17, 331-336): the paragraph at the foot of column 2, page 333 should read: Discretionary discharges. When the Tribunal do not consider that the patient must be discharged they may still, in any case, exercise a discretion to discharge (S72(1) line three). In these circumstances, but only for cases detained under Section 3, the Tribunal 'shall have regard to' (a) treatability and (b) (for mental illness and severe mental impairment only), viability (S72(2)(a)(b)).

THE COLLEGE

\section{Quarterly Business Meetings}

The College has reduced its numbers of major scientific meetings from four to two per annum. Business Meetings, however, will still be held four times a year. These will now take place during the Winter Meeting, after the March meeting of Council, during the Summer Meeting and after the October meeting of Council.

The agenda for those Business Meetings which will take place during the Winter and Summer Meetings will be circulated with papers for those conferences. A notice will appear in the February and September issues of the Psychiatric Bulletin informing members of the dates of the Council meetings which are to be followed by Business Meetings. The agenda will be included in this notice.

\section{Psychiatrists on the General Medical Council}

\section{Elections 1994}

The College will be publishing in the Psychiatric Bulletin the names of those psychiatrists who intend to stand for election to the General Medical Council in 1994. Members who have agreed to stand for election should contact the Secretary so that their names can be included in the printed list which will appear in the April Bulletin.

Vanessa Cameron, The Secretary. The Royal College of Psychiatrists 